\title{
A Framework for Human Resource Configurations in Knowledge-intensive Organizations
}

\author{
Xiaowan $\operatorname{Lin}^{1} \&$ Heng Tang ${ }^{2}$ \\ ${ }^{1}$ Department of Management and Marketing, University of Macau, Taipa, Macau \\ 2 Department of Accounting and Information Management, University of Macau, Taipa, Macau \\ Correspondence: Heng Tang, Department of Accounting and Information Management, University of Macau, \\ Avenida da Universidade, Taipa, Macau. Tel: 853-8822-4172.
}

Received: December 4, 2015

Accepted: December 18, 2015

Online Published: January 4, 2016

doi:10.5430/ijba.v7n1p1

URL: http://dx.doi.org/10.5430/ijba.v7n1p1

\begin{abstract}
The article identified two human resource (HR) configurations -- knowledge-based and commitment-based HR configurations -- which would particularly improve performance of knowledge-intensive organizations. The different mechanisms of their effects on organizational performance will be discussed. We argue that knowledge-based HR configuration will directly enhance the intellectual capital, which in turn affects organizational performance; whereas commitment-based HR configuration will influence organizational performance through improving employees' commitment to organization and lowering the rates of turnover and absenteeism. The model about the relationship of the two HR configurations (complementary vs. contradictory) is also proposed.
\end{abstract}

Keywords: human resource configurations, knowledge-intensive organizations, organizational performance, intellectual capital, commitment

\section{Introduction}

Building on the resource-based view of the firm (Barney, 1991), a developing body of research has reported positive associations between human resource (HR) systems and organizational performance and has also recognized the strategic role of HR management (HRM) (Arthur, 1994; Delaney \& Huselid, 1996; Delery \& Doty, 1996; Gong, Law, Chang, \& Xin, 2009; Guthrie, 2001; Huselid, 1995; Jiang, Lepak, Hu, \& Baer, 2012; Mak \& Akhtar, 2003; Rowden, 2001). Human resource constitutes an important resource that makes sustained competitive advantage possible when the human capital possessed by employees is unique, difficult to replicate, difficult to substitute, and adds sufficient value to organizational production processes (Barney, 1991).

Another significant developmental trend of the strategic HR literature is the increasing emphasis on the systemic or configurational perspective. Here, research assumes that a single HR practice cannot fully reflect a firm's wider propensity to invest in HR and that the effect of the whole HR system may be greater than the sum of effects of individual practices (e.g., Huselid, 1995). Furthermore, research assumes that firms perform better with internal complementarities or synergies in HR practices (e.g., Delery \& Doty, 1996; Takeuchi, Wakabayashi, \& Chen, 2003). Such a configurational perspective is employed in this article.

Although the literature in this area is developing rapidly, significant research needs remain to be addressed. With the increasing importance of knowledge in the contemporary competitive environment, knowledge-intensive firms have played increasingly important economic roles in environments characterized by ambiguity, rapid change, and hypercompetition, making them an important context in which to examine the effects of HR practices on organizational performance (Collins \& Clark, 2003; Collins \& Smith, 2006). In addition, the management of knowledge workers is much different from the management of production workers (Lepak \& Snell, 2002). However, few studies have focused on knowledge-intensive organizations or identified the HR practices best suited for the management of knowledge workers.

Research has paid attention to the processes through which HRM systems influence the principal intermediate variables that ultimately affect firm performance. For example, Guthrie (2001) and Huselid (1995) suggest that two dimensions of firm performance should be differentiated - namely, intermediate outcomes over which employees have direct control and final or distal outcomes (i.e., corporate performance). These studies reveal that effective HR 
practices affect intermediate outcomes, turnover, and productivity and that lower employee turnover and greater productivity, in turn, enhance corporate financial performance. Research has also examined positive work attitudes (e.g., commitment, job satisfaction) and behaviors (e.g., organizational citizenship behavior) as possible intermediate outcomes to link HRM systems and firm performance (e.g., Gong et al., 2009; Rodwell \& Teo, 2008; Sun, Aryee, \& Law, 2007). Intellectual capital (e.g., Ordóñez de Pablos, 2004; Youndt \& Snell, 2004) and relation-based variables, such as top management team social networks (Collins \& Clark, 2003) and social capital manifested by interaction density, cooperation, and a shared code (Jiang \& Liu, 2015), can also serve as plausible mediators to explain why HR practices can influence organizational performance. However, the question arises whether HR practices or HR configurations can affect organizational performance through the same mechanism, or whether different HR configurations have different direct objectives and effects. Scholars have called for a more integrative model that accounts for the multiple mechanisms through which HRM systems influence organizations (Jiang et al., 2012).

The theoretical framework proposed herein contributes to the strategic HR literature in the four ways. First, it addresses the characteristics of knowledge-intensive organizations and knowledge workers and identifies the specific HR configurations that match these organizations. Second, extending the debate on the similarities and differences between high-performance work systems (HPWSs) and high-commitment work systems (HCWSs), which have often been used interchangeably to describe the work systems that abandon Taylorist model and contribute to high firm performance, this study proposes two HR configurations-knowledge-based and commitment-based HR configurations - that differ in their basic approaches and objectives in managing human assets and describes their different effects on organization-level outcomes in knowledge-based organizations. Third, this study provides further understanding of the black box between HR practices and organizational performance. In particular, this study argues for different mechanisms of the effects of knowledge-based and commitment-based HR configurations on organizational performance and provides a more complete picture. Fourth, the study discusses the relationship between knowledge-based and commitment-based HR configurations and how they work together to affect firm performance.

\section{Controversies Surrounding the Distinction between HPWSs and HCWSs}

The literature on strategic HRM frequently uses the terms "high-performance work systems," "high-commitment work systems," "high-involvement systems," and "cooperative and innovative HRM practices" to describe the HR practices closely related to organizational performance in the modern competitive environment. These concepts highly overlap, and all are deemed as an abandonment of the traditional Taylorist model (Wood, 1999), which ignores commitment, involvement, and the well-being of employees and emphasizes narrowly designed specialized jobs, tight division of labor, and close control. However, are these various terms describing modern HR practices synonymous? Debate on this is ongoing, especially with regard to the distinction between HPWSs and HCWSs.

Some researchers have treated HPWSs as synonymous with HCWSs (e.g., Arthur, 1994; Guthrie, 2001; Huselid, 1995; MacDuffie, 1995; Takeuchi, Chen, \& Lepak, 2009; Woodman, 1989). The practices that research often includes in the two work systems are job flexibility, teamwork, intensive training, problem-solving groups, employee participation, and so on. These practices are considered not only to improve employee commitment but also to enhance enduring organizational competitiveness and performance; furthermore, empirical results have provided support for their superiority to traditional work systems. In other conditions, research has treated HCWSs as a subset of HPWSs, such that high-performance management combines high-commitment management practices and the quality assurance and inventory methods associated with total quality management (e.g., Lawler, Mohrman, \& Ledford, 1995). Research has also focused on the distinction between HPWSs and HCWSs (e.g., Delery \& Doty, 1996; Takeuchi et al., 2003). Here, HPWS is regarded as a management approach in which performance is targeted directly, not indirectly through attitudinal structuring, and includes factors such as skill formation, work structuring, quality control, and performance management. By contrast, HCWSs influence organizational performance by encouraging employee commitment and involvement (rather than influencing performance directly) through practices such as in-company welfare and long-term commitment practices. Jiang et al. (2012) differentiate skill-, motivation-, and opportunity-enhancing HR practices. Their typology reflects the distinction between HPWSs and HCWSs, such that skill- and opportunity-enhancing HR practices fall into the former while motivation-enhancing HR practices belong to the latter.

Extending the point of view that HPWSs and HCWSs are conceptually distinct terms, this research identifies two HR configurations that emphasize different direct objectives and may affect organizational performance though different mechanisms: commitment-based HR configuration and knowledge-based HR configuration. These two terms are used instead of HPWSs and HCWSs because, first, definitions and content of the latter two terms are ambiguous and 
inconsistent, due to the controversies surrounding their distinction, and, second, because these two proposed configurations are more specific to knowledge-intensive companies.

This paper argues that knowledge-based and commitment-based HR configurations are conceptually different in both their direct outcomes and the mechanisms through which they influence firm performance. The knowledge-based HR configuration aims to enhance intellectual capital directly to drive organizational performance, because intellectual capital is a key competitive advantage in the knowledge economy. Conversely, the commitment-based HR configuration focuses on setting up the psychological link between the organization and employees and developing employee commitment. Therefore, the commitment-based HR configuration affects firm performance by lowering the rate of turnover and absenteeism, thus preserving valuable intellectual capital.

Before identifying the detailed programs and practices included in these two HR configurations, it is necessary to explain why both are necessary in knowledge-intensive organizations. This paper first describes the characteristics of knowledge-intensive organizations and knowledge workers and then discuss the preferred HRM practices.

\section{Knowledge-intensive Organizations, Knowledge Workers, and Knowledge-based HR Configuration}

Firms largely compete through their products and technology and, as such, are becoming increasingly dependent on the workers who advance technology and supply unique and superior products (Collins \& Smith, 2006; Rogers, 2001). Knowledge management has become an increasing concern in modern business and organizations, especially in knowledge-intensive organizations (Perez \& de Pablos, 2003). Knowledge-intensive organizations (particularly high-tech firms) are characterized by their high level of intellectual work (Kelley \& Caplan, 1993) and the majority of knowledge workers. A large proportion of assets in knowledge-intensive organizations is tied up in intellectual human assets rather than in equipment or property (Rogers, 2001), and such organizations rely mainly on specialists' knowledge, expertise, and skills in their specific technical and functional domains (Kubo \& Saka, 2002). "Knowledge workers are those who use their heads more than their hands to produce value. They add value through their ideas, their analyses, their judgment, their syntheses, and their design" (Horibe, 1999, p. xi). Knowledge workers are generally highly educated and possess a high level of expertise (Rogers, 2001), and they are organizational assets (O'Donohue, Sheehan, Hecker, \& Holland, 2007). Intellectual capital has become a key competitive advantage in the knowledge economy, and knowledge workers who hold such knowledge power have become key determinants in whether knowledge-based and innovation-driven companies succeed or fail (Harrigan \& Dalmia, 1991).

Knowledge management involving continuous cycles of creativity and innovation is essential for knowledge workers and should be facilitated by organizational vision and support (Thite, 2004). The means by which organizations create a supportive environment and compatible culture for innovation has become a hot issue in the management area (e.g., Amabile, Conti, Coon, Lazenby, \& Herron, 1996; Claver, Llopis, Garcia, \& Molina, 1998; Ryan, 1995), in which the strategic role of HR management in innovation is increasingly emphasized. In knowledge-intensive organizations, knowledge and knowledge workers directly make up the production line, and HRM, which supports knowledge work systems, fulfills an important value-added organizational function in the production process (Rogers, 2001). Thus, HRM activities are directly related to the most valuable assets of the organization and, as such, improve the ability of the organization to achieve its goals successfully (Harrigan \& Dalmia, 1991).

From this discussion, it can be safely concluded that intellectual capital and knowledge utilization are proxy factors that influence organizational performance (e.g., Youndt \& Snell, 2004). Just as HPWSs target improvements in performance directly, rather than through employee commitment, as some researchers have suggested, the knowledge-based HR configuration identified herein includes HR practices geared toward enhancing three levels of intellectual capital: human, group, and organizational capital. HR practices related to human capital aim to help develop employees' knowledge and skill; HR practices related to group capital work to facilitate group interaction and knowledge sharing; and organizational capital requires HR activities that enable organizations to store knowledge in systems, routines, processes, and cultures. This research posits that the knowledge-based HR configuration drives organizational performance through intellectual capital. Although some practices under the knowledge-based HR configuration may enhance employee commitment, these enhancements are incidental to what the knowledge-based HR configuration emphasizes, and some practices may even have negative effects on employee commitment.

When employees possess firm-specific competencies that are difficult to imitate, they potentially create sustainable competitive advantages for organizations (Garavan, Morley, Gunnigle, \& Collins, 2001). Therefore, to improve organizational knowledge performance, firms should first emphasize the knowledge and skills possessed by employees, or their human capital (e.g., Garavan et al., 2001; Ordóñez de Pablos, 2004). Individual competence 
includes not only the knowledge and skills required to perform a given task but also the ability to learn and adapt to changes. The latter ability is more important in knowledge-intensive companies in modern competitive environments (e.g., Claver et al., 1998; Thite, 2004). Thus, organizations should support such skills through comprehensive selection and intensive training and development practices.

However, investing in human resource development at an individual level is insufficient (Garavan et al., 2001). Employees own human capital, but organizations do not; thus, when competent employees leave, organizations suffer great losses. Therefore, organizations should try to convert knowledge at the individual level to the group and organization level. To facilitate innovation and enhance quality, cooperative or interdependent behaviors are also indispensable (Schuler \& Jackson, 1987). Collaborative teamwork and egalitarian HRM practices can be implemented to achieve such goals. They can facilitate group interaction, encourage cooperative behavior, help diffuse knowledge within a firm, and create best-practice solutions (Cole, 1994; Schuler \& Jackson, 1987; Takeuchi et al., 2003; Youndt \& Snell, 2004). Knowledge resources derived from and exchanged through networks of relationships are called "social capital," another element of intellectual capital (Adler \& Kwon, 2002). This article uses the similar term "group capital" to describe knowledge within groups or derived from group interactions. Collaborative teamwork and egalitarian HRM practices can both help enhance group capital.

When knowledge is diffused within a firm, it is also necessary to institutionalize knowledge and codify experience to ensure their storage in systems, processes, databases, routines, patents, manuals, structures, and the like; such knowledge diffusion is called "organization capital" (Stewart, 1997). Only when knowledge is institutionalized can it be truly owned by the organization and stored for future use by all employees. Creating or filling knowledge storage devices is at the core of HRM geared toward developing organizational capital (Youndt \& Snell, 2004).

\subsection{The Knowledge-based HR Configuration and Human Capital}

The knowledge-based HR configuration comprises specific practices that directly aim to enhance intellectual capital or knowledge performance. Acquisition and development of skills are the two most important HR functions that help increase human capital (Hatch \& Dyer, 2004). Skill-acquire practices focus on talent selection and recruitment. When selecting and recruiting, organizations should not only expand the applicant pool by using a wide variety of recruiting sources (e.g., advertisement, employee referral, job agency, campus recruiting, Internet, headhunters) to increase the number of candidates screened but also gather more information about each applicant to make the hiring process more thorough and comprehensive. Koch and McGrath (1996) suggest that both functions help firms access high-quality new employees. In addition, because learning is highly required (Chan \& Scott-Ladd, 2004), knowledge-intensive organizations should put priority on candidates' potential to learn.

The non-firm-specific human capital embodied in new employees should be specialized and developed to become the basis of further learning and the driver of high productivity in organizations (Hatch \& Dyer, 2004). Employees can be trained and developed to help them acquire the knowledge and skills required to accomplish their tasks and to solidify their professional position in the organization (Takeuchi et al., 2003). Increasing investment in employee training and development is necessary (Matsuo, 2015). To expand its scope, training could entail introductory training for new employees, task-based training for experienced employees, and supervisory and managerial training for current or prospective managers. In addition, the frequency of employee training should be increased. Other practices not directly under the scope of training but related to development, including developmental feedback during performance management and rewards for employee knowledge/skill development, have also proved effective for human capital (Youndt \& Snell, 2004). Developmental feedback can provide useful information to help employees understand their potential and ways to improve their performance. Rewards for knowledge/skills can motivate employees to develop their human capital through multiple channels beyond the training programs provided. All these practices are categorized under the subset of knowledge-based HR configuration, labeled as "skill-developing practices."

\subsection{The Knowledge-based HR Configuration and Group Capital}

Collaborative teamwork and egalitarian HRM practices are two methods that improve group capital (Youndt \& Snell, 2004). As an important element of HPWS, teamwork has the power to help improve firm performance (Takeuchi et al., 2003). Teamwork can improve interaction density and cooperation which are essential to social capital and in turn organizational performance (Jiang \& Liu, 2015). Quality control circles and management by objectives are often considered indispensable to total quality management and are discussed in research on HPWSs (e.g., Cole, 1994). HR departments can further fulfill their organizational functions by emphasizing teamwork and cooperative behaviors, including team building in training and development programs, and implementing group-based incentives 
(e.g., gainsharing, group bonuses). Cross-functional teams and employee-customer teams could also provide the knowledge resources from both inside and outside the firm.

Egalitarian HRM practices can also help break down barriers to the transfer of information and best practices in organizations and cultivate an open and trusting culture to improve cooperative and interdependent behavior and reduce interpersonal competition (Schuler, \& Jackson, 1987; Youndt, \& Snell, 2004). Frequently employed egalitarian HRM practices include eliminating status symbols (e.g., identical uniforms, unreserved parking spaces), minimizing job classification, removing wage differentials, creating a flatter organizational structure, and decentralized decision making.

\subsection{The Knowledge-based HR Configuration and Organizational Capital}

HR Management is responsible for institutionalizing organizational capital. Youndt and Snell (2004) suggest that HR should encourage employees to establish and continually update the documents related to explicit knowledge, such as knowledge "yellow pages," notes of project processes, reports of "lessons learned," and documents of customer suggestions. HR should also empower employees to initiate work redesigns to help institutionalize tacit knowledge. All these practices are labelled as "institutionalizing knowledge" practices.

Figure 1 depicts our arguments on the knowledge-based HR configuration. The related propositions are put forth as follows:

Proposition 1a. Skill-acquiring and skill-developing practices in the knowledge-based HR configuration enhance human capital, which in turn improves firm performance.

Proposition 1b. Collaborative teamwork and egalitarian HRM practices in the knowledge-based HR configuration enhance group capital, which in turn improves firm performance.

Proposition 1c. Institutionalizing knowledge practices in the knowledge-based HR configuration enhance organizational capital, which in turn improves firm performance.

\section{Knowledge-based HR Intellectual capital}

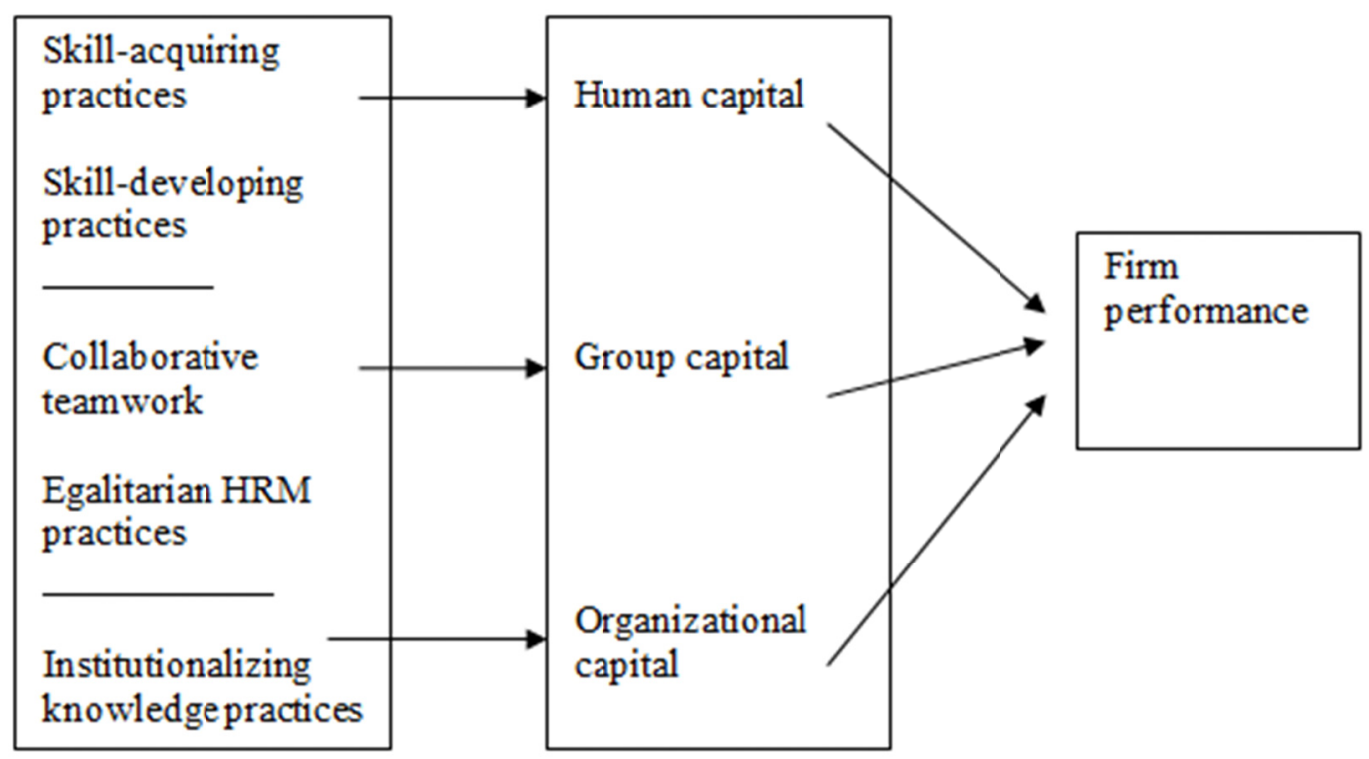

Figure 1. Strategic role of the knowledge-based HR configuration

\section{Knowledge Workers and Commitment-based HR Configuration}

The knowledge-based HR configuration can enhance intellectual capital and thereby lead to higher performance and competitiveness, but the objectives of these HR practices cannot be completely fulfilled unless employee commitment to the organization is incorporated and sustained. As Thite (2004) suggests, successful 
knowledge-intensive organizations are able to attract and retain best talent and, in turn, motivate them to generate and share knowledge to return the organization's investment in developing and nourishing their professional skills. Thus knowledge-intensive organizations should incorporate structures and management systems in the interest of efficiency and knowledge utilization, while also working to obtain commitment from knowledge workers. HR practices geared toward enhancing employee commitment are highly emphasized in the management of knowledge workers (e.g., Lepak \& Snell, 2002; O’Donohue et al., 2007).

Therefore, the commitment-based HR configuration captures the HR practices that aim to meet knowledge workers' need and encourage their commitment to the organization. Thus, the direct objective of this configuration is to enhance employee commitment and motivation and reduce the rate of turnover and absenteeism. Building on the strategic HRM, organizational learning, knowledge sharing, and organizational innovation literature streams, this paper proposes that the commitment-based HR configuration includes work autonomy and enrichment, high wage and profit sharing, internal promotion, in-company welfare, and long-term commitment practices.

Various theories and research attempting to identify dimensions of work environments related to creativity suggest that freedom or autonomy in the conduct of work and the provision of interesting and challenging work constitute important factors in determining management practices (e.g., Amabile et al., 1996; Claver et al., 1998). Rather, this paper we contends that knowledge-intensive organizations that guarantee employees' work autonomy and enrichment cater to the special needs of knowledge workers, resulting in greater commitment. Kubo and Saka (2002) argue that knowledge workers strive for greater power and autonomy in the workplace because they want to fulfill their roles and develop their expertise without control and constraints and avoid being assigned administrative tasks. O'Donohue et al. (2007) also emphasized that "Knowledge workers must be able to determine the focus of their task, and have the autonomy and responsibility for their own productivity" (p.77).

The systems governing pay for knowledge workers constitute another important issue that should be considered when organizations want to motivate them to fulfill their creativity and potential. As an element of the commitment-based HR configuration, high wages can attract and keep competent employees (Arthur, 1994). But they are not enough. Reward should be given in recognition of creativity and be perceived by employees as a confirmation of or a "bonus" of one's competence, thus motivating employees to perform jobs better and with more creativity in the future (Amabile et al., 1996). Incentive schemes geared to company success and profit sharing are also significant motivators for employees' commitment to achieving company goals (Delery \& Doty, 1996; Kubo \& Saka, 2002).

"The traditional lifelong organizational career model no longer remains relevant for many workers, particularly those active in the knowledge economy" (Donnelly, 2009, p. 319). The human capital knowledge workers possess endows them with more mobility across organizational boundaries when they pursue career advancement (Donnelly, 2009). To reduce knowledge workers' intention to leave, internal promotion opportunities can play an essential role (Delaney \& Huselid, 1996; Liu, Combs, Ketchen, \& Ireland, 2007; Pfeffer, 1998). Knowledge workers usually want to convey the perception that they are not upwardly bound (Lee \& Maurer, 1997). If internal upward mobility opportunities are available, most knowledge workers (80\% in Donnelly's [2009] survey) are likely to consider developing their careers with their current employers. Promotion from within can help keep firm-specific knowledge in the firm and allow firms to achieve returns from investments in training and development (Koch \& McGrath, 1996).Therefore, internal promotion should be a key theme in retaining and motivating knowledge workers.

Organizations typically use in-company welfare and long-term commitment practices, referred to as "retention-oriented management practices," as a means to promote employee organizational commitment and enhance behavioral outcomes (e.g., reducing turnover and absenteeism), especially in Japanese-style management (Takeuchi et al., 2003). In-company welfare practices, such as in-house cultural and athletic activities and newsletters, can build individual networks, lead to closer manager-employee relationships, and facilitate person-organization fit (Pfeffer, 1994). Other in-company welfare practices, such as housing loan plans, employee stock options, and long-term commitment practices (e.g., seniority-based promotion and wage increases, retirement allowance practice, long-term employment), can enhance employees' sense of belonging and security.

Figure 2 depicts the strategic roles of the commitment-based HR configuration. The arguments are formally stated as follows:

Proposition 2. The commitment-based HR configuration (i.e., work autonomy and enrichment, high wage and profit sharing, internal promotion, in-company welfare, and long-term commitment practices) improves organizational commitment and motivation and reduces turnover and absenteeism, thereby improving firm performance. 


\section{Commitment-based HR}

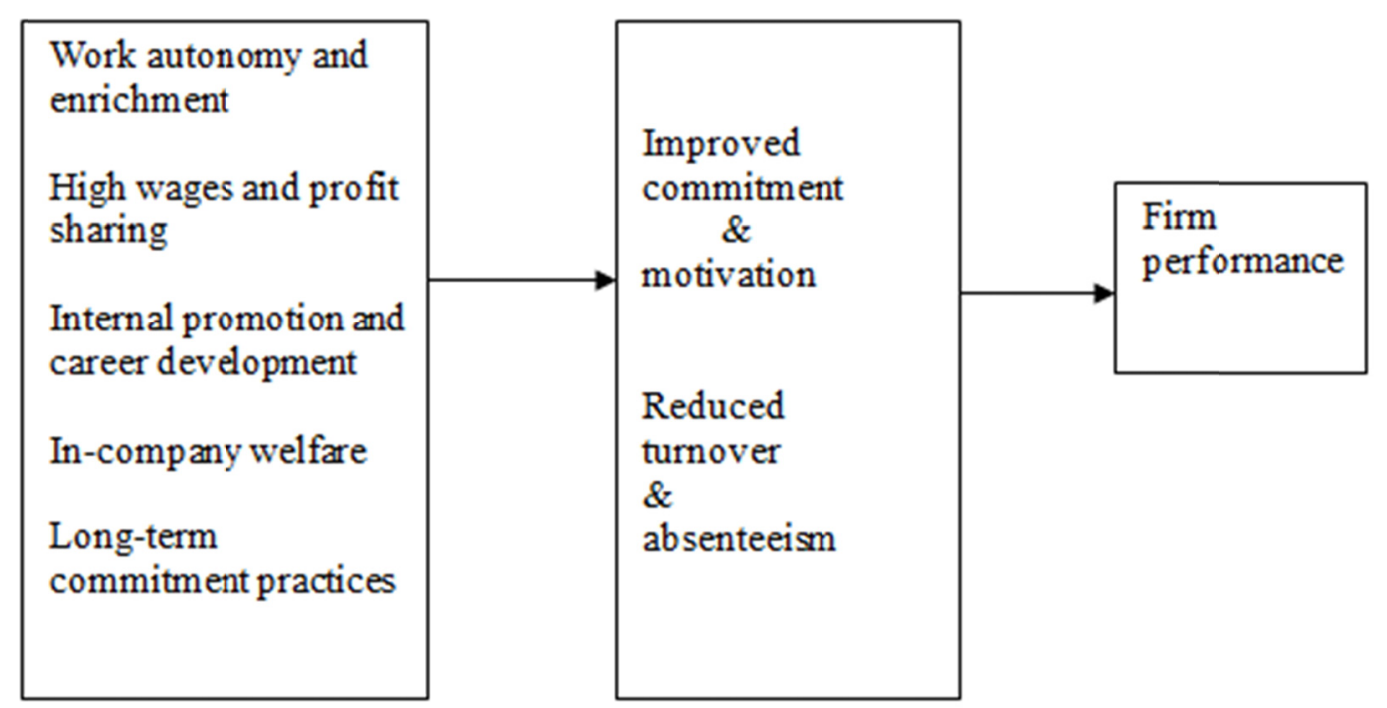

Figure 2. Strategic role of the commitment-based HR configuration

\section{Relationship between Knowledge-based and Commitment-based HR Configurations}

Both knowledge-based and commitment-based HR configurations are important in knowledge-intensive organizations, as discussed previously, but they affect firm performance through different processes. Thus, how are the two HR configurations related? Are they complementary or contradictory?

Because of their different direct objectives, distinctions and even contradictions can exist between knowledge-based and commitment-based HR configurations. The knowledge-based HR configuration, which focuses on the interests of the organization, may sometimes be in conflict with knowledge workers' needs and desires. While practices intended to enhance human capital are helpful for employees' self-development and may encourage their commitment to the organization, other practices aimed to increase both group and organizational capital may not lead to, and may even hurt, employee commitment. Mohrman and Von Glinow (1990) identify a strong preference for independence and a professional orientation, rather than an organizational focus, as two notable characteristics of high-tech workers. High-tech workers tend to manage their own careers by maximizing their own personal knowledge value and marketability and therefore may hesitate to share their knowledge and skills with others in the course of work projects; as such, they will face a dilemma if organizations encourage teamwork and knowledge-sharing behavior (Rogers, 2001). Knowledge workers may also be resistant to other practices, such as the obligation to institutionalize knowledge and comprehensive selection procedures. As a consequence, knowledge-based HR configuration practices can generate greater intellectual capital but have a weaker relationship with employee commitment and motivation. This means that knowledge-based and commitment-based HR configurations have differentiated effects on turnover and absenteeism.

However, knowledge-based and commitment-based HR configurations can also work in a complementary way. Lawler et al. (1995) contend that an HPWS (i.e., knowledge-based HR configuration) without employee commitment and involvement (i.e., commitment-based HR configuration) is not likely to affect performance positively and vice versa. Knowledge-based and commitment-based HR configurations should be integral parts of an HR work system. Some researchers (e.g., Takeuchi et al., 2003) consider employee commitment a precondition of organizational learning. Only when employees are retained and motivated to contribute can organizations act to improve productivity and enhance intellectual capital. Therefore, this framework suggests that the commitment-based configuration not only lowers the rate of turnover and absenteeism but also facilitates the knowledge-based HR configuration to enhance intellectual capital. That is, commitment-based and knowledge-based HR configurations work in a complementary way to enhance intellectual capital. The commitment-based HR configuration moderates the influence of the knowledge-based HR configuration on firm performance. 
With these arguments, this paper proposes a model that accounts for the relationship between knowledge-based and commitment-based HR configurations to shed light on how the two work together to improve performance of knowledge-intensive organizations. Fig. 3 illustrates the model.

Proposition 3a. Knowledge-based HR configuration practices have a weaker effect on employee commitment and turnover than commitment-based HR configuration practices.

Proposition 3b. Commitment-based and knowledge-based HR configurations work in a complementary way to enhance firm performance. The relationship between the knowledge-based HR configuration and firm performance is significantly positive only when commitment-based HR configuration practices are well implemented.

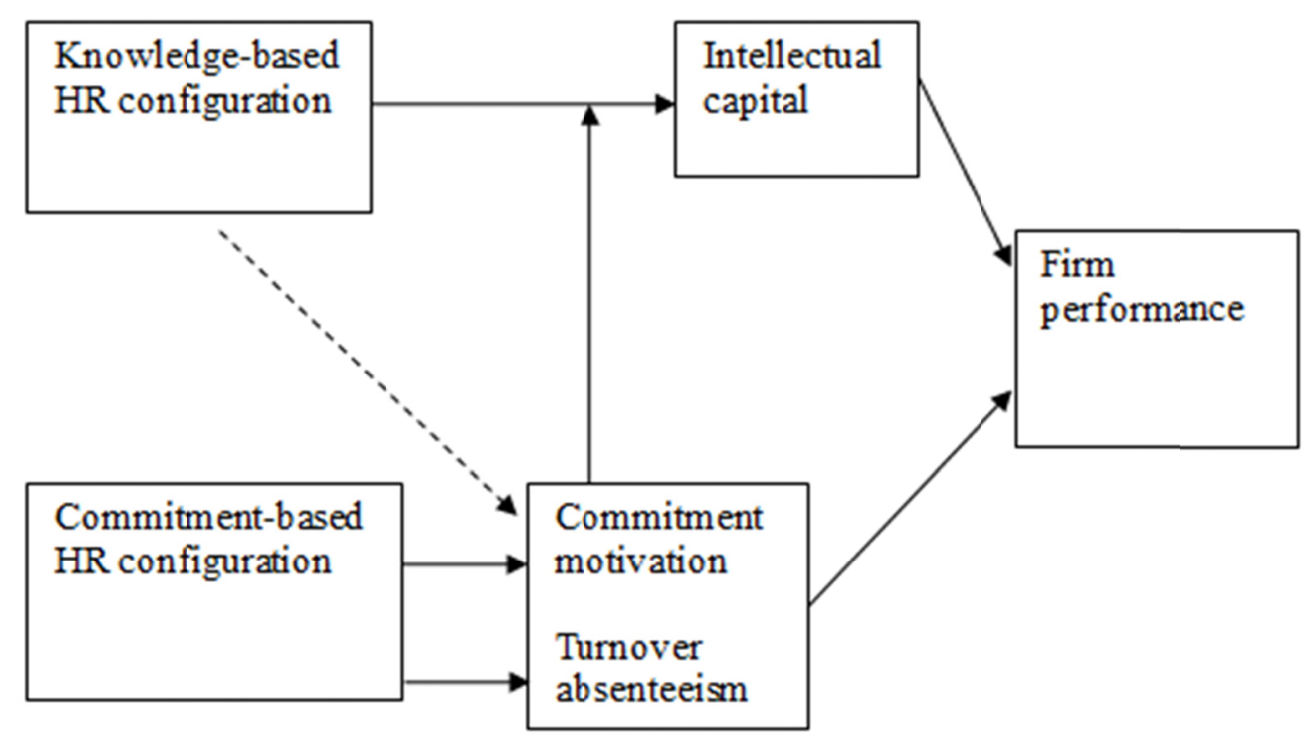

Figure 3. The relationship between knowledge-based and commitment-based HR configurations

\section{Discussion}

Although research has used HPWSs and HCWSs interchangeably to describe HRM systems that contribute to firm performance, some researchers (e.g., Delery \& Doty, 1993; Takeuchi et al., 2003) have identified them as conceptually distinct, with different expected outcomes and using different mechanisms to affect firm performance. Extending this line of argument, this paper identifies two HR configurations-knowledge-based and commitment-based HR configurations - in the context of knowledge-intensive organizations. Our proposed framework highlights the important roles of knowledge management and employee commitment in knowledge-intensive organizations and suggests that the knowledge-based HR configuration aims to improve intellectual capital (i.e., human, group, and organizational capital), which in turn contributes to high organizational performance. By contrast, the commitment-based HR configuration focuses on developing employee commitment and influencing organizational performance by reducing the rate of turnover and absenteeism.

Although knowledge-based and commitment-based HR configurations may have some conflicting outcomes, due to their different direct objectives, this paper emphasizes their complementary effects on organizational performance. As mentioned previously, the commitment-based HR configuration not only reduces turnover and absenteeism but also facilitates the knowledge-based HR configuration to improve intellectual capital, which is important for organizational performance.

The proposed framework helps shed light on how HR practices influence organizational performance. It suggests that different HR practice configurations affect organizational performance through distinct mechanisms. Exploring the mechanisms of the effect of HR practices would open up an important research avenue in strategic HR. As another important theoretical implication, the framework provides a plausible explanation for why some studies have not consistently found significant effects of HPWS, HCWS, or high-involvement HR practices on organizational performance (e.g., Cappelli \& Neumark, 2001; see also Edwards \& Wright, 2001); they may have ignored the complementary effects of different HR configurations. According to our model, the effect of the knowledge-based 
HR configuration may not be sufficient enough without the facilitation of the commitment-based HR configuration; the commitment-based HR configuration alone also cannot improve organizational performance sufficiently without the knowledge-based HR configuration to enhance intellectual capital directly. Therefore, further research should consider the combined effects of these two HR configurations simultaneously.

The proposed framework also provides important implications for HR practices in knowledge-intensive organizations. Faced with an environment characterized by hypercompetition and rapid change, knowledge-intensive organizations should adopt HR systems that help retain intelligent knowledge workers and encourage their organizational commitment and willingness to make a contribution. Simultaneously, they should strive to effectively manage knowledge to improve human, group, and organizational capital, to obtain a competitive advantage. To meet these goals, organizations should implement both knowledge-based and commitment-based HR configurations.

\section{Limitation and Future Research}

This paper suggests a testable model and research propositions which call for future qualitative or quantitative studies to test them. The framework is based on the characteristics of knowledge workers and knowledge-intensive organizations. It is worthy to explore whether this framework is particularly applicable to this type of organizations, or it is relatively universal and can apply to other non-knowledge-intensive organizations.

\section{References}

Adler, P. S., \& Kwon, S. (2002). Social capital: Prospects for a new concept. Academy of Management Review, 27(1), 17-40. http://dx.doi.org/10.5465/AMR.2002.5922314

Amabile, T. M., Conti, R., Coon, H., Lazenby, J., \& Herron, M. (1996). Assessing the work environment for creativity. Academy of Management Journal, 39(5), 1154-1184. http://dx.doi.org/10.2307/256995

Arthur, J. B. (1994). Effects of human resource systems on manufacturing performance and turnover. Academy of Management Journal, 37(3), 670-687. http://dx.doi.org/10.2307/256705

Barney, J. (1991). Firm resources and sustained competitive advantage. Journal of Management, 17(1), 99-120. http://dx.doi.org/10.1177/014920639101700108

Cappelli, T., \& Neumark, D. (2001). Do 'high-performance' work practices improve establishment-level outcomes? Industrial and Labor Relations Review, 54(4), 737-775. http://dx.doi.org/10.1177/001979390105400401

Chan, C. C. A., \& Scott-Ladd, B. (2004). Organizational learning: Some considerations for human resource practitioner. Asia Pacific Journal of Human Resources, 42(3), 336-347. http://dx.doi.org/10.1016/1047-8310(88)90005-3

Claver, E., Llopis, J., Garcia, D., \& Molina, H. (1998). Organizational culture for innovation and new technological behavior. Journal of High Technology Management Research, 9(1), 55-68. http://dx.doi.org/10.1016/1047-8310(88)90005-3

Cole, R. E. (1994). Different quality paradigms and their implications for organizational learning. In M. Aoli, \& R. Dore (Eds.), The Japanese firm: The sources of competitive strength (66-83). Oxford: Oxford University Press. http://dx.doi.org/10.1093/acprof:oso/9780198288152.003.0004

Collins, C. J., \& Clark, K. D. (2003). Strategic human resource practices, top management team social networks, and firm performance: The role of human resource practices in creating organizational competitive advantage. Academy of Management Journal, 46(6), 740-751. http://dx.doi.org/10.2307/30040665

Collin, C. J., \& Smith, K. G. (2006). Knowledge exchange and combination: The role of human resource practice in the performance of high-technology firms. Academy of Management Journal, 49(3), 544-560. http://dx.doi.org/10.5465/AMJ.2006.21794671

Delaney, J. T., \& Huselid, M. A. (1996). The impact of human resource management practices on perceptions of organizational performance. Academy of Management Journal, 39(4), 949-969. http://dx.doi.org/10.2307/256718

Delery, J. E., \& Doty, D. H. (1996). Modes of theorizing in strategic human resource management: Test of universalistic, contingency, and configurational performance predictions. Academy of Management Journal, 39(4), 802-835. http://dx.doi.org/10.2307/256713

Donnelly, R. (2009). Career behavior in the knowledge economy: Experiences and perceptions of career mobility among management and IT consultants in the UK and the USA. Journal of Vocational Behavior, 75(3), 319-328. http://dx.doi.org/10.1016/j.jvb.2009.04.005 
Edwards, P., \& Wright, M. (2001). High-involvement work system and performance outcomes: The strength of variable, contingent and context-bound relationships. International Journal of Human Resource Management, 12(3), 568-585. http://dx.doi.org/10.1080/713769651

Garavan, T. N., Morley, M., Gunnigle, P., \& Collins, E. (2001). Human capital accumulation: The role of human resource development. Journal of European Industrial Training, 25(2), 48-53. http://dx.doi.org/10.1108/EUM0000000005437

Gong, Y., Law, K. S., Chang, S., \& Xin, K. R. (2009). Human resources management and firm performance: The differential role of managerial affective and continuance commitment. Journal of Applied Psychology, 94(1), 263-275. http://dx.doi.org/10.1037/a0013116.

Guthrie, J. P. (2001). High-involvement work practices, turnover, and productivity: Evidence from New Zealand. Academy of Management Journal, 44(1), 180-190. http://dx.doi.org/10.2307/3069345

Harrigan, K. R., \& Dalmia, G. (1991). Knowledge workers: The last bastion of competitive advantage. Planning Review, 19(6), 4-9. http://dx.doi.org/10.1108/eb054337

Hatch, N. W., \& Dyer, J. H. (2004). Human capital and learning as a source of sustainable competitive advantage. Strategic Management Journal, 25(12), 1155-1178. http://dx.doi.org/10.1002/smj.421

Horibe, F. (1999). Managing knowledge workers: New skills and attitudes to unlock the intellectual capital in your organization. John Wiley \& Sons, Inc. New York, NY, USA.

Huselid, M. A. (1995). The impact of human resource management practices on turnover, productivity, and corporate financial performance. Academy of Management Journal, 38(3), 635-672. http://dx.doi.org/10.2307/256741

Jiang, J. Y., \& Liu, C.-W. (2015). High performance work systems and organizational effectiveness: The mediating role of social capital. Human Resource Management Review, 25(1), 126-137. http://dx.doi.org/10.1016/j.hrmr.2014.09.001

Jiang, K., Lepak, D. P., Hu, J., \& Baer, J. C. (2012). How does human resource management influence organizational outcomes? A meta-analytic investigation of mediating mechanisms. Academy of Management Journal, 55(6), 1264-1294. http://dx.doi.org/10.5465/amj.2011.0088

Kelley, R., \& Caplan, J. (1993). How bell labs creates star performers. Harvard Business Review, 71(4), $128-139$. http://dx.doi.org/10.1016/0737-6782(94)90018-3

Koch, M. J., \& McGrath, R. G. (1996). Improving labor productivity: Human resource management policies do matter. Strategic Management $\quad$ Journal, http://dx.doi.org/10.1002/(SICI)1097-0266(199605)17:5<335::AID-SMJ814>3.3.CO;2-I

Kubo, I., \& Saka, A. (2002). An inquiry into the motivations of knowledge workers in the Japanese financial industry. Journal of Knowledge Management, 6(3), 262-271. http://dx.doi.org/10.1108/13673270210434368

Lawler, E., Mohrman, S. A., \& Ledford, G. E. (1995). Creating high performance organization practices and of employee involvement and total quality management in Fortune 1000 companies. Jossey-Bass, San Francisco, SF, USA

Lee, T. W., \& Maurer, S. D. (1997). The retention of knowledge workers with the unfolding model of voluntary turnover. Human Resource Ranagement Review, 247-275. http://dx.doi.org/10.1016/S1053-4822(97)90008-5

Lepak, D. P., \& Snell, S. A. (2002). Examining the human resource architecture: The relationship among human capital, employment, and human resource configurations. Journal of Management, 28(4), 517-543. http://dx.doi.org/10.1016/S0149-2063(02)00142-3

Liu, Y., Combs, J., Ketchen, D. J., Jr., \& Ireland, R. D. (2007). The value or human resource management for organizational performance. Business Horizons, 50(6), 503-511. http://dx.doi.org/10.1016/j.bushor.2007.07.002

MacDuffie, J. P. (1995). Human resource bundles and manufacturing performance: Organizational logic and flexible production systems in the world auto industry. Industrial and Labor Relations Review, 48(2), 197-221. http://dx.doi.org/10.2307/2524483

Mak, S. K. M., \& Akhtar, S. (2003). Human resource management practices, strategic orientations and company performance: A correlation study of publicly listed companies. Journal of American Academy of Business, 2(2), 510-515. 
Matsuo, M. (2015). Human resource development programs for knowledge transfer and creation: The case of the Toyota technical development corporation. Journal of Knowledge Management, 19(6), 1186-1203. http://dx.doi.org/10.1108/JKM-03-2015-0108

Mohrman, S. A., \& Von Glinow, M. A. (1990). High technology: An introduction. In M. A. Won Gilnow, \& S. A. Mohrman (Eds.), Managing complexity in high technology organizations. Oxford University Press, New York, 3-14.

O'Donohue, W., Sheehan, C., Hecker, R., \& Hollamd, P. (2007). The psychological contract of knowledge workers. Journal of Knowledge Management, 11(2), 73-82. http://dx.doi.org/10.1108/13673270710738924

Ordóñez de Pablos, P. (2004). Human resource management systems and their role in the development of strategic resources: Empirical evidence. Journal of European Industrial Training, 28(6), 474-489. http://dx.doi.org/10.1108/03090590410542701

Perez, J. R, \& de Pablos, P. O. (2003). Knowledge management and organizational competitiveness: a framework for human capital analysis. Journal of Knowledge Management, 7(3), 82-91. http://dx.doi.org/10.1108/13673270310485640

Pfeffer, J. (1994). Competitive advantage through people: Unleashing the power of the work force. Harvard Business School Press, Boston.

Pfeffer, J. (1998). The human equation: Building profits by putting people first. Harvard Business School Press, Boston

Rodwell, J. J., \& Teo, S. T. T. (2008). The influence of strategic HRM and sector on perceived performance in health services organizations. International Journal of Human Resource Management, 19(10), 1825-1841. http://dx.doi.org/10.1080/09585190802323934

Rogers, E. W. (2001). A theoretical look at firm performance in high-tech organizations: What does existing theory tell us. Journal of High Technology Management Research, 12(1), 39-61. http://dx.doi.org/10.1016/S1047-8310(00)00038-9

Rowden, R. W. (2002). High performance and human resource characteristics of successful small manufacturing and processing companies. Leadership \& Organizational Development Journal, 23(2), 79-83. http://dx.doi.org/10.1108/01437730210419206

Ryan, M. (1995). Human resource management and politics of knowledge: Linking the essential knowledge base of the organization to strategic decision making. Leadership \& Organizational Development Journal, 16(5), 3-10. http://dx.doi.org/10.1108/01437739510088464

Schuler, R. S., \& Jackson, S. E. (1987). Linking competitive strategies with human resource management practices. Academy of Management Executive, 1(3), 207-219.

Stewart, T. A. (1997). Intellectual capital, Doubleday-Currency, New York.

Sun, K. Y., Aryee, S., \& Law, K. S. (2007). High performance human resource practices, citizenship behavior, and organizational performance: A relational perspective. Academy of Management Journal, 50(3), 558-577. http://dx.doi.org/10.5465/AMJ.2007.25525821

Takeuchi, N., Wakabayashi, M., \& Chen, Z. (2003). The strategic HRM configuration for competitive advantage: Evidence from Japanese firms in China and Taiwan. Asia Pacific Journal of Management, 20(4), 447-480. http://dx.doi.org/10.1023/A:1026386925473

Takeuchi, R., Chen, G., \& Lepak, D. P. (2009). Through the looking glass of a social system: Cross-level effects of high performance work systems on employees' attitudes. Personnel Psychology, 62(1), 1-29. http://dx.doi.org/10.1111/j.1744-6570.2008.01127.x

Thite, M. (2004). Strategic positioning of HRM in knowledge-based organizations. The Learning Organization, 11(1), 28-44. http://dx.doi.org/10.1108/09696470410515715

Wood, S. (1999). Getting the measure of the transformed high-performance organization, British Journal of Industrial Relations, 37(3), 391-417. http://dx.doi.org/10.1111/1467-8543.00134

Woodman, R. W. (1989). Organizational change and development: New arenas for inquiry and action. Journal of Management, 15(2), 205-228. http://dx.doi.org/10.1177/014920638901500205

Youndt, M. A., \& Snell, S. A. (2004). Human resource configurations, intellectual capital, and organizational performance. Journal of Managerial Issues, 16(3), 337-360. 